\title{
PENGARUH PERPUTARAN PERSEDIAAN, PERPUTARAN PIUTANG \\ DAN PERTUMBUHAN PENJUALAN TERHADAP LIKUIDITAS \\ PADA PERUSAHAAN INDUSTRI BARANG KONSUMSI YANG TERDAFTAR DI BURSA EFEK INDONESIA
}

Romasi Lumban Gaol

\begin{abstract}
Abstrak
Tujuan dari penelitian ini adalah untuk menemukan bukti secara empiris pengaruh tingkat perputaran persediaan, tingkat perputaran piutang dan pertumbuhan penjualan terhadap likuiditas. Data yang digunakan dalam penelitian ini merupakan data sekunder berupa laporan keuangan perusahaan industri barang konsumsi yang terdaftar di Bursa Efek Indonesia. Periode amatan dimulai dari tahun 2011-2013. Teknik analisis menggunakan regresi linier berganda. Hasil statistik dengan uji $\mathrm{F}$ diperoleh $\mathrm{F}_{\text {hitung }}$ sebesar 5,663 dengan tingkat signifikan sebesar 0,005 , sehingga $\mathrm{H}_{1}$ diterima. Artinya, perputaran persediaan, perputaran piutang dan pertumbuhan penjualan berpengaruh positif dan signifikan secara simultan terhadap likuiditas. Dilihat dari hasil uji t, disimpulkan bahwa perputaran persediaan dan perputaran piutang tidak memiliki pengaruh yang signifikan terhadap likuiditas, sedangkan tingkat pertumbuhan penjualan berpengaruh negatif signifikan terhadap likuiditas. Saran untuk peneliti selanjutnya diharapkan menambahkan variabel lain karena dalam penelitian ini variabel independen hanya mampu menjelaskan variabel dependen sebesar 14,6\%. Peneliti selanjutnya diharapkan menggunakan objek penelitian selain perusahaan barang konsumsi. Pengukuran likuiditas dapat diukur menggunakan rasio lain selain rasio lancar, seperti rasio cepat, dan rasio kas.
\end{abstract}

Kata kunci: Perputaran Persediaan, Perputaran Piutang dan Pertumbuhan Penjualan dan Likuiditas

\section{PENDAHULUAN}

Kelangsungan hidup perusahaan dipengaruhi oleh banyak hal antara lain likuiditas perusahaan itu sendiri. Menurut Wild et al. (2010) "Likuiditas (liquidity) mengacu pada kemampuan perusahaan untuk memenuhi kewajiban jangka pendeknya". Likuiditas merupakan kemampuan untuk mengubah aktiva menjadi kas atau kemampuan untuk memperoleh kas. Pentingnya likuiditas dapat dilihat dengan mempertimbangkan dampak yang berasal dari ketidakmampuan perusahaan memenuhi kewajiban jangka pendeknya.

Diantara berbagai ukuran likuditas, rasio lancar digunakan untuk mengukur likuiditas dari suatu perusahaan. Rasio ini menunjukkan kemampuan aktiva lancar menutupi kewajiban-kewajiban lancar yang dimiliki perusahaan. Semakin besar perbandingan aktiva lancar dengan 
kewajiban lancar maka semakin tinggi kemampuan perusahaan menutupi kewajiban jangka pendeknya.

Unsur aktiva lancar yang paling besar jumlahnya adalah persediaan. Apabila suatu perusahaan dapat mengelola persediaan dengan baik, maka perusahaan tersebut secepatnya dapat mengubah persediaan yang tersimpan melalui penjualan yang akan menghasilkan piutang dan kemudian akan bertransformasi menjadi kas pada saat penagihan.

Semakin tingginya tingkat perputaran persediaan menyebabkan perusahaan semakin cepat dalam melakukan penjualan barang dagang sehingga semakin cepat pula bagi perusahaan dalam memperoleh dana baik dalam bentuk uang tunai (kas) ataupun piutang. Besar kecilnya aktiva lancar tersebut nantinya akan turut mempengaruhi rasio lancarnya.

Salah satu strategi alternatif yang dipakai di setiap perusahaan guna memperlancar penjualan hasil produksinya adalah dengan melakukan penjualan secara kredit. Namun penjualan kredit akan menimbulkan resiko bagi perusahaan, baik resiko keterlambatan pelunasan piutang oleh pelanggan, hingga resiko tidak terbayarnya piutang tersebut. Jika terjadi hal seperti ini, maka tingkat perputaran piutang menjadi menurun, sehingga pengembalian modal kerja akan menurun. Perputaran piutang rendah maka kondisi modal yang ada juga akan dikatakan rendah sehingga dikatakan illiquid atau tidak liquid. Sebaliknya perputaran piutang yang tinggi maka kondisi modal akan semakin tinggi dan perusahaan dikatakan liquid.

Aktivitas utama perusahaan dalam pencapaian laba adalah penjualan. Jika perusahaan cermat, maka penjualan akan menjadi penyumbang keuntungan terbesar perusahaan. Penjualan dapat dilakukan dengan dua cara yaitu dengan tunai dan kredit yang disertai dengan persyaratan tertentu. Perusahaan tentunya akan lebih menyukai transaksi penjualan yang dilakukan secara tunai karena akan segera menerima kas. Namun kenyataannya, penjualan yang sering terjadi adalah penjualan kredit. Hal ini dapat disebabkan oleh beberapa alasan yaitu besarnya nilai penjualan sementara pembeli tidak memiliki kecukupan kas.

Disisi lain penjualan secara kredit juga akan menguntungkan penjual karena akan memperluas pasar. Semakin tinggi tingkat pertumbuhan penjualan produk, maka likuiditas akan semakin tinggi dikarenakan penjualan mencakup kas dan piutang yang termasuk kategori aktiva lancar yang merupakan komponen dalam menghitung tingkat likuiditas. 
Ridwan (2009) menyatakan bahwa terdapat pengaruh antar perputaran piutang terhadap tingkat likuiditas, sedangkan Milawati (2010) menemukan bahwa tingkat perputaran piutang tidak berpengaruh signifikan terhadap tingkat likuiditas. Putra (2010) menyatakan bahwa tingkat pertumbuhan penjualan dan perputaran piutang tidak berpengaruh secara signifikan terhadap tingkat likuiditas. Hasil penelitian Andina (2012) menyebutkan bahwa tingkat pertumbuhan penjualan tidak berpengaruh signifikan terhadap likuiditas. Tetapi perputaran piutang berpengaruh signifikan terhadap tingkat likuiditas (Andina, 2012)

Hasil penelitian Vendy Widhiatmojo dan Supriyanto (2012) menunjukkan bahwa tidak terdapat pengaruh yang signifikan perputaran piutang terhadap likuiditas, dan perputaran persediaan barang tidak memiliki pengaruh yang signifikan terhadap likuiditas. Namun hasil penelitian secara simultan menunjukkan bahwa perputaran piutang, perputaran kas dan perputaran persediaan barang secara bersama-sama tidak berpengaruh secara signifikan terhadap likuiditas.

Melihat ketidakkonsistenan baik antara teori dengan hasil penelitian maupun antar hasil penelitian sebelumnya mendorong peneliti untuk melakukan penelitian dengan objek yang berbeda, yaitu sektor industri barang konsumsi yang terdaftar di Bursa Efek Indonesia untuk mengetahui apakah hasil penelitian sebelumnya dapat digeneralisasi secara umum. Selanjutnya masalah yang diteliti dirumuskan dalam bentuk pertanyaan sebagai berikut, Apakah perputaran persediaan, perputaran piutang, dan tingkat pertumbuhan penjualan berpengaruh secara signifikan terhadap likuiditas (current ratio) pada perusahaan industri barang konsumsi yang terdaftar di Bursa Efek Indonesia (BEI) ?.

\section{TELAAH TEORI DAN PENGEMBANGAN HIPOTESIS}

\section{Telaah Teori}

a. Perputaran Persediaan

Persediaan adalah sejumlah barang jadi, bahan baku, barang dalam proses yang dimiliki perusahaan dengan tujuan untuk dijual atau diproses lebih lanjut (Rudianto, 2009). Sedangkan menurut (Dunia, 2008) persediaan dapat didefinisikan sebagai aset berwujud yang diperoeh perusahaan untuk dijual kembali dalam kegiatan normal perusahan dan yang diperoleh untuk lebih dulu dan dijual.

Rasio Perputaran Persediaan (Inventory Turnover) digunakan untuk mengukur perjalanan persediaan sampai kembali menjadi uang kas (Moeljadi, 2006). Apabila rasio yang diperoleh tinggi, ini menunjukkan 
perusahaan bekerja secara efesien dan likuid persediaan semakin baik. Demikian pula apabila perputaran persediaan rendah berarti perusahaan bekerja secara tidak efesien atau tidak produktif dan banyak barang persediaan yang menumpuk. Hal ini akan mengakibatkan investasi dalam tingkat pengembalian yang rendah (Kasmir, 2012).

Menurut James C.Van Horne (2005) " Perputaran Persediaan adalah rasio antara harga pokok penjualan terhadap persediaan rata-rata menunjukkan seberapa cepat persediaan tersebut dapat dijual". Rasio ini dihitung sebagai berikut:

$$
\text { Inventory Turnover }=\frac{\text { Harga Pokok Penjualan }}{\text { Rata }- \text { rata Persediaan }}
$$

\section{b. Perputaran Piutang}

Piutang merupakan klaim keuangan terhadap perusahaan atau perorangan (Horngren, Harrison JR, \& Bamber, 2006). Sedangkan menurut (Rudianto, 2009) Piutang adalah klaim perusahaan atas uang, barang, atau jasa kepada pihak lain akibat transaksi di masa lalu. Menurut Kasmir (2012), bahwa semakin tinggi rasio perputaran piutang menunjukan bahwa modal kerja yang ditanamkan dalam piutang semakin rendah (bandingkan dengan rasio tahun sebelumnya) dan tentunya kondisi ini bagi perusahaan semakin baik. Sebaliknya jika rasio semakin rendah ada over investment dalam piutang. Hal ini jelas adalah rasio perputaran piutang memberikan pemahaman tentang kualitas piutang dan kesuksesan penagihan piutang.

Rasio Perputaran Piutang (Receivable Turnover) merupakan rasio yang digunakan untuk mengukur barapa lama penagihan piutang selama satu periode atau berapa kali dana yang ditanamkan dalam piutang ini berputar dalam satu periode. Semakin tinggi rasio menunjukkan bahwa modal kerja yang ditanamkan dalam piutang semakin rendah (dibandingkan dengan rasio tahun sebelumnya) dan tentunya kondisi ini bagi perusahaan semakin baik. Sebaliknya jika rasio semakin rendah ada over investment dalam piutang (Kasmir, 2012).

Perputaran piutang yang semakin tinggi adalah semakin baik karena berarti modal kerja yang ditanamkan dalam bentuk piutang akan semakin rendah. Naik turunnya perputaran piutang ini akan dipengaruhi oleh hubungan perubahan penjualan dan perubahan piutang. Misalnya perputaran piutang turun bila penjualan turun tetapi piutang meningkat. Turunnya piutang tidak sebanyak turunnya penjualan, naiknya penjualan 
tidak sebanyak naiknya piutang, penjualan turun tetapi piutang tetap, atau piutang naik tetapi penjualan tetap (Jumingan, 2011). berikut:

Adapun rumus menurut (Wild \& K.R, 2010:45) adalah sebagai

$$
\text { Receivable Turn Over }=\frac{\text { Penjualan Kredit }}{\text { Rata }- \text { rata Piutang }}
$$

\section{c. Pertumbuhan Penjualan}

Penjualan adalah penerimaan yang diperoleh dari pengiriman barang dagangan atau dari penyerahan pelayanan dalam bursa sebagi barang pertimbangan yaitu dalam bentuk tunai peralatan kas atau harta lainnya (Higgins, 2003).

Menurut Kasmir (2012) rasio pertumbuhan merupakan rasio yang menggambarkan kemampuan perusahaan dalam mempertahankan posisi ekonominya. Pertumbuhan penjualan merupakan indikator penting dari penerimaan pasar atas produk dan/atau jasa perusahaan tersebut, dimana pendapatan yang dihasilkan dari penjualan akan dapat digunakan untuk mengukur tingkat pertumbuhan penjualan.

Keown (2008), menjelaskan bahwa tingkat pertumbuhan berkelanjutan tersebut menggambarkan tingkat pertumbuhan penjualan perusahaan jika perusahaan ingin mempertahankan rasio keuangannya sekarang dan tidak ingin menjual secara paksa ekuitas pemegang saham.

Menurut Horne (2005), tingkat pertumbuhan penjualan dihitung dengan rumus sebagai berikut:

$$
g=\frac{\mathrm{S} 1-\mathrm{S} 0}{\mathrm{~S} 0} \times 100 \%
$$

Keterangan
$\mathrm{g}=$ Growth Sales Rate (tingkat pertumbuhan penjualan)
S1 = Total Current Sales (total penjualan selama periode berjalan)
S0 = Total Sales For Last Period (total penjualan periode yang lalu)

\section{d. Likuiditas}

Menurut Sunyoto (2013), bahwa analisis likuiditas digunakan untuk mengukur kemampuan perusahaan dalam memenuhi kewajiban finansial jangka pendeknya, baik kewajiban dalam membiayai proses produksi maupun kewajiban keluar perusahaan. Rasio likuiditas atau sering juga disebut rasio modal kerja merupakan rasio yang digunakan untuk 
mengukur seberapa likuidnya suatu perusahaan. Rasio likuiditas berfungsi untuk menunjukkan atau mengukur kemampuan perusahaan dalam memenuhi kewajibannya yang sudah jatuh tempo (Kasmir, 2012).

Ukuran rasio likuiditas adalah current ratio, quick ratio, dan cash ratio. Ukuran yang peling sering digunakan untuk mengukur likuiditas perusahaan adalah current ratio atau juga dapat disebut rasio lancar yang perhitungan likuiditas didasarkan pada perbandingan total nilai aktiva lancar dan total nilai kewajiban lancar perusahaan.

Menurut Kasmir (2012), rasio lancar atau current ratio merupakan alat untuk mengukur kemampuan perusahaan dalam memenuhi kewajiban finansial jangka pendeknya atau utang yang segera jatuh tempo pada saat ditagih secara keseluruhan. Dari hasil pengukuran rasio, apabila rasio lancar rendah dapat dikatakan bahwa perusahaan kurang modal untuk membayar utang. Namun, apabila hasil pengukuran rasio tinggi belum tentu kondisi perusahaan sedang baik, hal ini dapat saja terjadi karena kas tidak digunakan sebaik mungkin.

Menurut Kasmir (2012), rasio ini dapat diitentukan dengan membandingkan aktiva lancar dengan utang lancar atau dengan rumus yang digunakan:

$$
\text { Current Ratio }=\frac{\text { Aktiva Lancar }(\text { Current Assets })}{\text { Utang Lancar }(\text { Liabilities Assets })}
$$

\section{Pengembangan Hipotesis}

\section{a. Pengaruh Perputaran Persediaan Penjualan Terhadap Likuiditas}

Perputaran persediaan menunjukkan berapa kali persediaan yang dimiliki oleh perusahaan diganti dalam satu periode, diganti artinya dibeli dan dijual kembali. Perputaran persediaan yang lambat menunjukkan lamanya persediaan tersimpan di perusahaan, sehingga hal ini dapat memperbesar biaya persediaan, dan akan mempengaruhi laba perusahaan.

Semakin tingginya tingkat perputaran persediaan menyebabkan perusahaan semakin cepat dalam melakukan penjualan barang dagang sehingga semakin cepat pula bagi perusahaan dalam memperoleh dana baik dalam bentuk uang tunai (kas) ataupun piutang. Besar kecilnya aktiva lancar tersebut nantinya akan turut mempengaruhi rasio lancarnya. Vendy Widhiatmojo dan Supriyanto (2012) menyimpulkan bahwa perputaran persediaan barang tidak memiliki pengaruh yang signifikan terhadap likuiditas baik secara parsial maupun simultan. 


\section{b. Pengaruh Perputaran Piutang Terhadap Likuiditas}

Menurut Keown (2008), piutang merupakan aktiva lancar yang paling likuid setelah kas. Bagi sebagian perusahaan, piutang merupakan pos yang penting karena merupakan bagian aktiva lancar perusahaan yang jumlahnya cukup besar. Di dalam menelusuri likuiditas perusahaan salah satu yang dipelajari adalah kemampuan perusahaan untuk mengubah piutang usaha dalam periode tertentu dan dengan mengukur berapa kali piutang usaha berputar dalam setahun atau disebut rasio perputaran piutang.

Ridwan (2009), menyimpulkan perputaran piutang mempunyai pengaruh yang cukup berarti terhadap likuiditas. Semakin tinggi tingkat perputaran piutang, maka semakin besar pula kemampuan perusahaan menutupi kewajiban lancarnya. Dalam penelitiannya menunjukan bahwa terdapat pengaruh antara perputaran piutang terhadap tingkat likuiditas.

\section{c. Pengaruh Pertumbuhan Penjualan Terhadap Likuiditas}

Menurut Stice dkk (2009), metode yang paling umum diterapkan untuk menghadapi ketidakpastian penagihan kas adalah metode penjualan cicilan. Dalam metode ini laba diakui pada saat kas dibayarkan dan bukannya pada saat penjualan.

Menurut Horne dan Wachowicz (2005), analisis laporan dana memberi pandangan kedalam operasi keuangan perusahaan yang akan sangat berharga terutama bagi yang berperan sebagai manajer keuangan yang mempelajari rencana ekspansi lama dan mendatang milik perusahaan dan mempelajari dampaknya terhadap likuiditas. Ketidakseimbangan dalam penggunaan dana dapat dideteksi hingga tindakan yang tepat dapat diambil.

Falahi (2010), menunjukan bahwa pertumbuhan penjualan berpengaruh secara signifikat terhadap likuiditas pada perusahaan retail yang terdaftar di Bursa Efek Indonesia.

\section{d. Kerangka Pemikiran Teoritis}

Kerangka pemikiran disusun untuk menggambarkan pengaruh antara variabel independen dengan variabel dependen. Kerangka pemikiran dapat digambarkan seperti di berikut: 
Pengaruh Perputaran Persediaan, Perputaran Piutang, dan Pertumbuhan Penjualan Terhadap Likuiditas

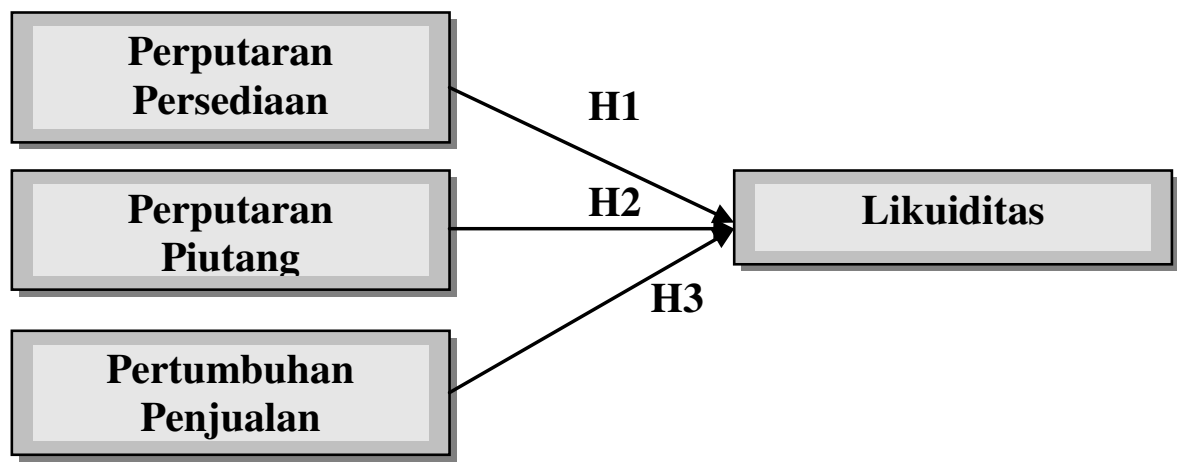

\section{e. Hipotesis Penelitian}

Berdasarkan telaah teoritis, pengembangan hipotesis, serta kerangka pemikiran teoritis, maka diajukan hipotesa sebagai berikut:

H1: Perputaran persediaan berpengaruh signifikan terhadap likuiditas.

$\mathrm{H} 2$ : Perputaran piutang berpengaruh signifikan terhadap likuiditas.

H1: Tingkat pertumbuhan penjualan berpengaruh signifikan terhadap likuiditas

\section{METODE PENELITIAN}

\section{Populasi dan Teknik Pengambilan Sampel}

Populasi penelitian ini adalah perusahaan sektor industri barang konsumsi yang terdaftar pada Bursa Efek Indonesia (BEI) periode 2011 sampai dengan 2013 yang berjumlah 34 perusahaan. Teknik pengambilan sampel dengan menggunakan metode purposive sampling. Berikut ini kriteria pengambilan sampel penelitian ini adalah :

a. Perusahaan sektor industri barang konsumsi yang terdaftar BEI periode 2011 sampai dengan 2013.

b. Perusahaan sektor industri barang konsumsi yang mengalami kenaikan penjualan dalam sektor industri barang konsumsi yang terdaftar BEI periode 2011 sampai dengan 2013.

c. Perusahaan sektor industri barang konsumsi yang mempublikasikan laporan keuangan lengkap di BEI periode 2011 sampai dengan 2013.

Berdasarkan kriteria pemilihan sampel penelitian, maka didapat sampel 23, observasi selama 3 (tiga) tahun, sehingga observasi pengamatan menjadi $23 \times 3=69$. 


\section{Definisi Operasional dan Pengukuran Variabel}

a. Perputaran persediaan

Perputaran Persediaan adalah rasio antara harga pokok penjualan terhadap persediaan rata-rata James C.Van Horne, 2005 dan Wachowicz. Rasio ini dihitung dengan rumus:

$$
\text { Inventory Turnover }=\frac{\text { Harga Pokok Penjualan }}{\text { Rata }- \text { rata Persediaan }}
$$

b. Perputaran Piutang

Menurut Kasmir (2012), perputaran piutang merupakan rasio yang digunakan untuk mengukur berapa lama penagihan piutang selama satu periode atau berapa kali dana yang ditanam dalam piutang ini berputar dalam satu periode. Perputaran piutang dihitung dengan rumus:

$$
\text { Receivable Turn Over }=\frac{\text { Penjualan Kredit }}{\text { Rata }- \text { rata Piutang }}
$$

c. Tingkat Pertumbuhan Penjualan

Menurut James C.Van Horne, 2005 dan Wachowicz (2005), tingkat pertumbuhan berkelanjutan (sustainable growth rate - SGR) adalah persentase tahunan maksimum kenaikan dalam penjualan yang dapai dicapai berdasarkan pada berbagai rasio target operasi, utang dan pembayaran dividen. Tingkat pertumbuhan penjualan diukur dengan rumus:

$$
g=\frac{\mathrm{S} 1-\mathrm{S} 0}{\mathrm{~S} 0} \times 100 \%
$$

d. Likuiditas (Current Ratio)

Likuiditas digunakan untuk mengukur kemampuan perusahaan dalam memenuhi kewajiban finansial jangka pendeknya, baik kewajiban dalam membiayai proses produksi maupun kewajiban keluar perusahaan (Sunyoto, 2013). Current ratio merupakan alat untuk mengukur kemampuan perusahaan dalam memenuhi kewajiban finansial jangka pendeknya. Rasio ini dapat ditentukan dengan membandingkan aktiva lancar dengan utang lancar.

$$
\text { Current Ratio }=\frac{\text { Aktiva Lancar }(\text { Current Assets })}{\text { Utang Lancar }(\text { Liabilities Assets })}
$$




\section{Teknik Analisis Data}

Teknik analisis data yang digunakan dalam penelitian ini adalah analisis regresi linear berganda, koefisien determinasi, uji statistik F dan uji statistik t. Adapun analisis yang dilakukan adalah sebagai berikut:

\section{a. Analisis Regresi Berganda}

Menurut Ghozali (2013), dalam analisis regresi, selain mengukur kekuatan hubungan antara dua varibel atau lebih, juga menunjukan arah hubungan antar variabel dependen dengan variabel independen. Untuk mengetahui pengaruh variable bebas dan variable terikat digunakan rumus analisis regresi linear berganda sebagai berikut :

$$
\mathrm{Y}=\mathrm{a}+\mathrm{b}_{1} \mathrm{X}_{1}+\mathrm{b}_{2} \mathrm{X}_{2}+\mathrm{b}_{3} \mathrm{X}_{3}+\mathrm{e}
$$

Dimana :

$$
\mathrm{Y}=\text { Likuiditas }
$$

$\mathrm{a}=$ Konstanta

$\mathrm{b}_{1}=$ Koefisien Regresi Variabel $\mathrm{X}_{1}$ (perputaran persediaan)

$\mathrm{b}_{2}=$ Koefisien Regresi Variabel $\mathrm{X}_{2}$ (perputaran piutang) penjualan)

$\mathrm{b}_{3}=$ Koefisien Regresi Variabel $\mathrm{X}_{2}$ (tingkat pertumbuhan

$\mathrm{X}_{1}=$ Variabel perputaran persediaan

$\mathrm{X}_{2}=$ Variabel perputaran piutang

$\mathrm{X}_{3}=$ Variabel tingkat pertumbuhan penjualan

$\mathrm{e}=$ Persentase kesalahan $(5 \%)$

\section{b. Uji Asumsi Klasik}

Sebelum model regresi digunakan untuk menguji hipotesis, tentunya model tersebut harus bebas dari gejala asumsi klasik karena model yang baik harus memenuhi kriteria BLUE (Best Linear Unbiased Estimator). Adapun uji asumsi klasik yang digunakan adalah, Uji Normalitas, normalitas diuji dengan melihat grafik histogram (Ghozali, 2013). Uji Multikolinieritas, pengujian multikolinearitas dilakukan dengan melihat VIF (Variance Inflation Factor) antar variabel independen, (Ghozali, 2013)

Uji Autokorelasi, pengujian autokorelasi menggunakan uji Durbin - Watson (DW test). Uji Heteroskedastisitas Uji heteroskedastisitas dilakukan dengan melihat grafik plot antara nilai prediksi variabel terikat(dependen) yaitu ZPRED dengan residualnya SRESID (Ghozali, 2013:139). 


\section{c. Pengujian hipotesis penelitian}

Pengujian hipotesis dilakukan dengan uji koefisien determinasi, uji statistik F dan uji statistik t.

\section{HASIL PENELITIAN DAN PEMBAHASAN}

\section{Statistik Deskriptif}

Statistik deskriptif dalam penelitian ini disajikan untuk memberikan informasi karakteristik variabel penelitian khususnya mengenai mean dan deviasi standar. Pengukuran mean merupakan cara yang paling umum digunakan untuk mengukur nilai sentral dari suatu distribusi data. Deviasi standar merupakan perbedaan antara nilai data yang diteliti dengan nilai rata-ratanya. Berikut ini disajikan hasil statistik deskriptif pengujian pengaruh Perputaran Persediaan Perputaran Piutang, Tingkat Pertumbuhan Penjualan terhadap Likuiditas pada Tabel 1 berikut ini:

\section{Tabel 1}

HASIL STATISTIK DESKRIPTIF

\begin{tabular}{|l|r|r|r|r|r|}
\hline & $\mathrm{N}$ & $\begin{array}{c}\text { Minimu } \\
\mathrm{n}\end{array}$ & $\begin{array}{r}\text { Masimu } \\
\mathrm{m}\end{array}$ & \multicolumn{1}{c|}{ Mean } & \multicolumn{1}{c|}{$\begin{array}{c}\text { Std. } \\
\text { Deviation }\end{array}$} \\
\hline Perputaran Persediaan & 69 & 0.38 & 56.00 & 5.7927 & 9.85997 \\
Perputaran Piutang & 69 & 0.49 & 48.53 & 10.3459 & 11,06535 \\
Tingkat Pertumbuhan & 69 & 0.01 & 3.48 & 0.2535 & 0,44795 \\
Penjualan & 69 & 0.67 & 11.73 & 2.8313 & 2.19099 \\
Likuiditas & 69 & & & & \\
Valid N (listwise) & & & & & \\
\hline
\end{tabular}

Sumber: data sekunder diolah 2015

Pada Tabel 1 menunjukkan nilai minimum, nilai maksimum, nilai rata-rata (mean), dan standar deviasi dari variabel, perputaran piutang $\left(\mathrm{X}_{1}\right)$, perputaran piutang $\left(\mathrm{X}_{2}\right)$, tingkat pertumbuhan penjualan $\left(\mathrm{X}_{3}\right)$ dan likuiditas (Y) dengan rincian sebagai berikut:

1. Variabel perputaran persediaan memiliki jumlah sampel sebanyak 69, dengan nilai minimum sebesar 0,38 dan nilai maksimum 56,00 sedangkan nilai rata-rata (mean) sebesar 5,7927 dengan standar deviasi (simpangan baku) sebesar 9,85997.

2. Variabel perputaran piutang memiliki jumlah sampel sebanyak 69, dengan nilai minimum 0,49 dan nilai maksimum 48,53 sedangkan nilai rata-rata (mean) sebesar 10,3459 dengan standar deviasi (simpangan baku) sebesar 11,06535. 
3. Variabel tingkat pertumbuhan penjualan memiliki jumlah sampel sebanyak 69, dengan nilai minimum sebesar 0,01 dan nilai maksimum 3,48 sedangkan nilai rata-rata (mean) sebesar 0,2535 dengan standar deviasi (simpangan baku) sebesar 0,44793.

4. Variabel Likuiditas memiliki jumlah sampel sebanyak 69, dengan nilai minimum 0,67 dan nilai maksimum 11,73 sedangkan nilai rata-rata (mean) sebesar 2,8313 dengan standar deviasi (simpangan baku) sebesar 2,19099.

\section{Hasil Uji Asumsi Klasik}

pengujian asumsi klasik yang meliputi uji normalitas, uji multikolinieritas, uji autokorelasi dan uji heteroskedastisitas.

\section{a. Uji Normalitas}

Untuk menguji apakah grafik variabel memiliki distribusi normal atau tidak, dilakukan pengujiannya sebagai berikut:

\section{Gambar: Uji Normalitas}

Histogram

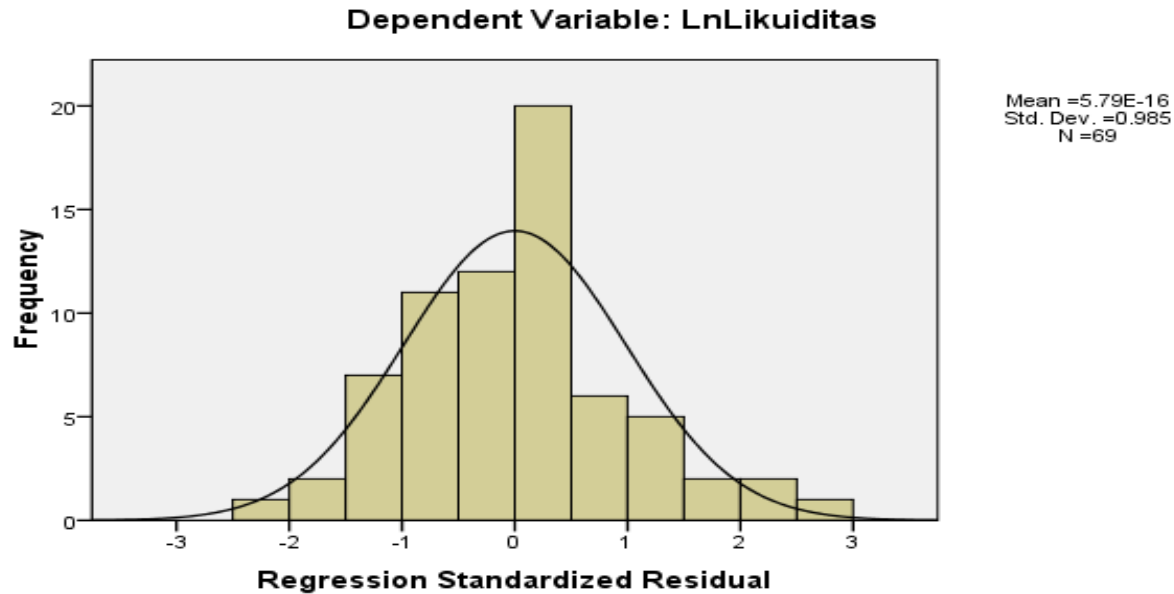

Sumber: data sekunder diolah 2015

Berdasarkan Gambar 5.1 terlihat bahwa hasil bentuk kurva tidak menceng ke kiri ataupun ke kanan sehingga hal itu menyatakan residual berdistribusi secara normal. 


\section{b. Uji Multikolonieritas}

Pengujian multikolonieritas dilakukan dengan melihat VIF antar variabel independen. Berikut adalah hasil uji multikolinieritas :

\section{Tabel 2}

Uji Multikolonieritas

\begin{tabular}{|l|c|c|}
\hline \multirow{2}{*}{\multicolumn{1}{|c|}{ Model }} & \multicolumn{2}{|c|}{ Collinearity Statistics } \\
\cline { 2 - 3 } & Tolerance & VIF \\
\hline 1 Constant & & \\
Perputaran Persediaan & .911 & 1,098 \\
Perputaran Piutang & .993 & 1.007 \\
Tingkat Pertumbuhan & .942 & 1,061 \\
Penjualan & & \\
\hline
\end{tabular}

Sumber: data sekunder diolah 2015

Pada Tabel 2, menunjukkan bahwa besarnya nilai tolerance yang diperoleh untuk perputaran persediaan sebesar 0,911 perputaran piutang sebesar 0,993 dan tingkat pertumbuhan penjualan adalah sebesar 0,942. Nilai VIF (Variance Inflation Factor) yang diperoleh perputaran persediaan adalah sebesar 1,098 dan perputaran piutang sebesar 1,007 dan tingkat pertumbuhan penjualan adalah sebesar 1,061. Karena nilai tolerance yang diperoleh untuk setiap variabel lebih besar dari 0,10 dan nilai VIF yang diperoleh untuk setiap variabel lebih kecil dari 10, maka artinya data bebas dari adanya gejala multikolinearitas.

\section{c. Uji Autokorelasi}

Uji autokorelasi digunakan untuk menguji apakah dalam suatu model regresi linier terdapat korelasi antara kesalahan pengganggu pada periode $\mathrm{t}$ dengan kesalahan pengganggu pada periode $\mathrm{t}-1$ (sebelumnya). Berikut ini adalah hasil pengujian autokorelasi dengan menggunakan uji Durbin - Watson (DW).

Tabel 3

Uji Autokorelasi

Model Summaryb

\begin{tabular}{|c|c|c|c|c|c|}
\hline Model & $\mathrm{R}$ & $\begin{array}{c}\mathrm{R} \text { Square } \\
\text { Adjusted }\end{array}$ & $\mathrm{R}$ Square & $\begin{array}{c}\text { Std. Error of } \\
\text { the Estimate }\end{array}$ & $\begin{array}{c}\text { Durbin- } \\
\text { Watson }\end{array}$ \\
\hline 1 & $.383^{\mathrm{a}}$ &, 146 &, 121 & 0,57575 & 1,687 \\
\hline
\end{tabular}

a. Predictor: (Constant), Perputaran Persediaan, Perputaran Piutang,

Tingkat Pertumbuhan Penjualan

b. Dependen Variabel: Likuiditas

Sumber: data sekunder diolah 2015 
Pada Tabel 3 menunjukkan bahwa nilai DW yang diperoleh adalah sebesar 1,687. Nilai dl dan du yang diperoleh dengan $\mathrm{K}$ (jumlah variabel bebas $)=3$ dan $\mathrm{N}$ (jumlah sampel) $=69$ adalah 1,5507 dan 1,6697. Karena nilai DW yang diperoleh lebih besar dari nilai du dan lebih kecil dari nilai $(4-\mathrm{du}=4-1,6697=2,3303)$ yaitu $1,6697<1,687<2,3303$ artinya tidak terdapat autokorelasi.

\section{d. Uji Heteroskedastisitas}

Uji heteroskedastisitas dilakukan dengan menggunakan uji glejser. Model regresi yang baik adalah yang homoskedastisitas atau yang tidak terjadi heteroskedastisitas. Berikut ini hasil uji Glejser.

\section{Tabel 4}

\section{Hasil Uji Glejser}

\section{Coefficientsa}

\begin{tabular}{|c|c|c|c|c|c|c|}
\hline \multirow{2}{*}{\multicolumn{2}{|c|}{ Model }} & \multicolumn{2}{|c|}{$\begin{array}{l}\text { Unstandardized } \\
\text { Coefficients }\end{array}$} & $\begin{array}{l}\text { Standardized } \\
\text { Coefficients }\end{array}$ & \multirow[t]{2}{*}{$t$} & \multirow[t]{2}{*}{ Sig. } \\
\hline & & $B$ & Std. Error & Beta & & \\
\hline & (Constant) & 606 & ,142 & & 4,288 & 000 \\
\hline & Perputran Persediaan & -.111 & .077 & -.193 & -1.439 & .154 \\
\hline & $\begin{array}{l}\text { Perputaran Piutang } \\
\text { Tingkat Pertumbuhan }\end{array}$ &,- 108 & ,054 & -239 & $-1,989$ & 051 \\
\hline & Pernjualan &,- 017 & .049 &,- 041 & -.343 &, 733 \\
\hline
\end{tabular}

a. Dependent Variable: Likuiditas $(\mathrm{Y})$

Sumber: data sekunder diolah 2015

Pada Tabel 4 menunjukkan bahwa pada model regresi tidak terjadi gejala heteroskedastisitas karena nilai signifikannya yang diperoleh untuk perputaran persediaan $0,154>0,05$, nilai signifikan yang diperoleh untuk perputaran piutang $0,051>0,05$, dan nilai signifikan untuk tingkat pertumbuhan penjualan $0,773>0,05$.

\section{Hasil Analisis Data}

Pengolahan data dan pengujian hipotesis dalam penelitian ini dilakukan dengan menggunakan alat bantu statistic yaitu program software komputer SPSS.

\section{a. Analisis Regresi Linier Berganda}

Hasil analisis regresi berganda dapat dilihat pada Tabel 5 berikut ini: 
Tabel 5

HASIL ANALISIS REGRESI LINIER BERGANDA

Coefficients $^{a}$

\begin{tabular}{|c|c|c|c|c|c|}
\hline \multirow{2}{*}{ Model } & \multicolumn{2}{|c|}{$\begin{array}{c}\text { Unstandardized } \\
\text { Coefficients }\end{array}$} & $\begin{array}{l}\text { Standardized } \\
\text { Coefficientst }\end{array}$ & \multirow[t]{2}{*}{$t$} & \multirow[t]{2}{*}{ Sig. } \\
\hline & $B$ & Standar Error & Beta & & \\
\hline $1 \quad$ (Constant) & .658 & 20.621 & & 2.925 & .005 \\
\hline Perputran Persediaan & -.241 & .145 & -.142 & -1.663 & .100 \\
\hline Perputaran Piutang & -.138 & .086 & -.184 & -1.609 & .112 \\
\hline Tingkat Pertumbuhan & & & & 2070 & \\
\hline Pernjualan & -.239 & $0 / 8$ & -.351 & $-3.0 / 8$ & .003 \\
\hline
\end{tabular}

a. Dependent Variable: Likuiditas (Y)

Sumber: data sekunder diolah 2015

berikut:

Berdasarkan Tabel 5.6 diatas diperoleh rumus regresi sebagai $\mathrm{Y}=0,658-0,241 \mathrm{X}_{1}-0,138 \mathrm{X}_{2}-0,239 \mathrm{X}_{3}+\varepsilon$

Hasil interpretasi dari regresi tersebut adalah sebagai berikut:

1. Nilai a sebesar 0,658 artinya jika variabel perputaran persediaan $\left(X_{1}\right)$, perputaran piutang $\left(\mathrm{X}_{2}\right)$ dan tingkat pertumbuhan penjualan $\left(\mathrm{X}_{3}\right)$ dianggap konstan, maka likuiditas perusahaan sektor industri barang konsumsi yang terdaftar di Bursa Efek Indonesia adalah sebesar 0,658.

2. Nilai koefisien perputaran persediaan $\left(X_{1}\right)$ sebesar -0,241. Ini menunjukkan bahwa setiap kenaikkan tingkat pertumbuhan penjualan satu kali maka likuiditas (Y) akan mengalami penurunan sebesar 0,241 .

3. Nilai koefisien perputaran piutang $\left(\mathrm{X}_{2}\right)$ sebesar $-0,138$. Ini menunjukkan bahwa setiap kenaikkan perputaran piutang satu kali maka likuiditas (Y) akan mengalami penurunan sebesar -0,138.

4. Nilai koefisien tingkat pertumbuhan penjualan $\left(X_{3}\right)$ sebesar $-0,239$. Ini menunjukkan bahwa setiap kenaikkan tingkat pertumbuhan penjualan satu kali maka likuiditas (Y) akan mengalami penurunan sebesar 0,239 .

\section{b. Koefisien Determinasi $\left(\mathbf{R}^{2}\right)$}

Koefisien Determinasi $\left(\mathrm{R}^{2}\right)$ adalah angka yang menunjukkan besarnya derajat atau kemampuan distribusi variabel independen (X) dalam menjelaskan dan menerangkan variabel dependen (Y). Besar koefisien 
determinasi adalah antara nol dan satu $\left(0<\mathrm{R}^{2}<1\right)$. Berikut ini nilai koefisien determinasi $\left(\mathrm{R}^{2}\right)$ penelitian ini :

Tabel 6

Koefisiensi Determinasi

Model Summaryb

\begin{tabular}{|c|c|c|c|c|}
\hline Model & $\mathrm{R}$ & $\begin{array}{c}\text { R Square } \\
\text { Adjusted }\end{array}$ & R Square & $\begin{array}{c}\text { Std. Error of the } \\
\text { Estimate }\end{array}$ \\
\hline 1 & $.383^{\mathrm{a}}$ &, 146 &, 121 & 0,57575 \\
\hline
\end{tabular}

a. Predictor: (Constant), Perputaran Persediaan, Perputaran Piutang,

Tingkat Pertumbuhan Penjualan

b. Dependen Variabel: Likuiditas

Sumber: data sekunder diolah 2015

Pada Tabel 6 hasil analisis regresi dapat dilihat secara keseluruhan. Nilai $\mathrm{R}$ sebesar 0,383 menunjukan bahwa korelasi atau keeratan hubungan antara perputaran persediaan, perputaran piutang dan tingkat pertumbuhan penjualan dengan likuiditas mempunyai hubungan yang rendah yaitu sebesar 38,3\%. Nilai Adjusted $R$ Square (Adj $R^{2}$ ) atau koefisien determinasi $\left(\mathrm{R}^{2}\right)$ sebesar 0,146 mengindikasikan bahwa variasi perputaran pesediaan, perputaran piutang, dan tingkat pertumbuhan penjualan hanya menjelaskan variasi likuiditas sebesar $14,6 \%$ sedangkan sisanya $85,4 \%$ dipengaruhi oleh faktor-faktor lain diluar variabel yang diteliti antara lain Perputaran Modal Kerja, kas, dan dividen.

\section{IV.3.3 Pengujian Hipotesis Secara Simultan (Uji - F)}

Uji - F digunakan untuk menguji apakah variabel independen secara bersama-sama mempengaruhi variabel dependen. Berikut ini hasil pengujian hipotesis secara simultan adalah sebagai berikut :

Tabel 5.8

Hasil Uji Hipotesis Secara Simultan ANOVAb

\begin{tabular}{|rl|r|r|r|r|c|}
\hline \multicolumn{2}{|c|}{ Model } & \multicolumn{1}{c|}{$\begin{array}{c}\text { Sum of } \\
\text { Squares }\end{array}$} & \multicolumn{1}{c|}{ df } & Mean Square & F & \multicolumn{1}{c|}{ Sig. } \\
\hline 1 & Regression & 3.754 & 3 & 1.877 & 5.663 & $.005^{\mathrm{a}}$ \\
& Residual & 21.878 & 65 & .331 & & \\
& Total & 25.632 & 68 & & & \\
\hline
\end{tabular}

a. Predictor: (Constant), Perputaran Persediaan, Perputaran Piutang, Tingkat Pertumbuhan Penjualan

b. Dependen Variabel: Likuiditas

Sumber: data sekunder diolah 2015 
Pada Tabel 5.8 uji - $\mathrm{F}$ diperoleh nilai $\mathrm{F}_{\text {hitung }}$ sebesar 5,663 dengan tingkat signifikan sebesar 0,005 sedangkan nilai $F_{\text {tabel }}$ sebesar 3,13. Hal ini menunjukkan bahwa $F_{\text {hitung }}>F_{\text {tabel }}$ maka Ho ditolak dan Ha diterima, artinya perputaran persediaan, perputaran piutang, tingkat pertumbuhan penjualan secara simultan berpengaruh signifikan terhadap likuiditas pada perusahaan industri barang konsumsi yang terdapat di Bursa Efek Indonesia.

\section{c. Pengujian Hipotesis Secara Parsial (Uji t)}

Uji t digunakan untuk mengetahui pengaruh variabel independen terhadap variabel dependen secara parsial. Hasil pengujian dengan uji t adalah sebagai berikut:

\section{Tabel 8}

Hasil Uji Hipotesis Secara Parsial Coefficients ${ }^{\mathrm{a}}$

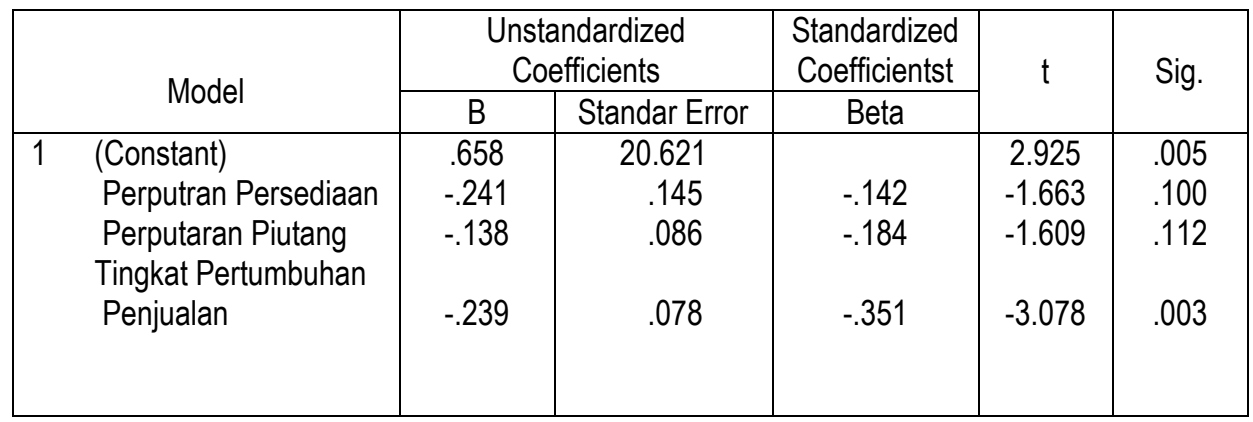

a. Dependent Variable: Likuiditas $(\mathrm{Y})$

Sumber: data sekunder diolah , 2015

Hasil pengujian statistik secara parsial sebagai berikut :

1. Perputaran persediaan menunjukkan t hitung sebesar -1,663 dengan nilai signifikansi 0,100 dan $\mathrm{t}$ tabel 1,986. Karena $-1,663<1,986$ dan nilai signifikansi $0,100>0,05$ sehingga Ho gagal ditolak. Maka dapat disimpulkan bahwa Perputaran Persediaan secara parsial tidak berpengaruh terhadap likuiditas.

2. Perputaran piutang mempunyai nilai t hitung sebesar $-1,609$ dengan nilai signifikan 0,112 dan $\mathrm{t}$ tabel 1,9394. Karena thitung $-1,609<\mathrm{t}_{\text {tabel }} 1,9394$ dan nilai signifikan 0,112>0,05 sehingga Ho gagal ditolak, artinya perputaran piutang secara parsial tidak berpengaruh signifikan terhadap likuiditas pada perusahaan industri barang konsumsi yang terdaftar di Bursa Efek Indonesia. 
3. Tingkat pertumbuhan penjualan mempunyai nilai signifikan $0,003<0,05$ selain itu hasil $t_{\text {hitung }}-3,078>t_{\text {tabel }}$ 1,688 yang berarti bahwa Ho ditolak dan Ha diterima. Dengan demikian secara parsial tingkat pertumbuhan penjualan berpengaruh negatif dan signifikan terhadap likuiditas pada perusahaan industri barang konsumsi yang terdaftar di Bursa Efek Indonesia.

\section{Pembahasan Hasil Penelitian}

\section{a. Pengaruh Perputaran Persediaan Terhadap Likuiditas.}

Hasil dari pengujian membuktikan bahwa perputaran persediaan tidak memiliki pengaruh yang signifikan terhadap likuiditas. Dengan nilai signifikansi t 0,100 >0.05, sehingga Ho gagal ditolak. Penelitian ini berbeda dengan penelitian yang dilakukan oleh Suseno (2009) yang menyatakan bahwa perputaran persediaan memiliki pengaruh yang signifikan terhadap likuiditas. Hasil penelitian ini menunjukkan bahwa perputaran persediaan tidak memiliki pengaruh yang signifikan terhadap likuiditas, maka perputaran persediaan tidak dapat dijadikan bahan pertimbangan pengaruh dalam likuiditas perusahaan industri barang konsumsi yang terdaftar di Bursa Efek Indonesia selama periode penelitian. Perbedaan ini dikarenakan adanya perbedaan jenis industri perusahaan yang digunakan dengan penelitian sebelumnya. Penelitian yang dilakukan oleh Suseno (2009) menggunakan objek satu organisasi saja yang terdapat dalam industri kosmetik dan keperluan rumah tangga.

Di dalam industri barang konsumsi bahan baku utamanya bermacammacam. Periode atau lama waktu penyimpanan persediaan pada perusahaan barang konsumsi memiliki ciri yang berbeda dengan industri kosmetik dan keperluan rumah tangga lainnya, periode atau lama waktu penyimpanan bahan baku barang konsumsi tidak sama untuk semua jenis persediaan. Hal ini tentunya mempengaruhi perputaran persediaan pada industri barang konsumsi. Faktor-faktor tersebutlah yang menyebabkan terjadinya perbedaan pada hasil penelitian pengaruh perputaran persediaan terhadap likuiditas.

\section{b. Pengaruh Perputaran Piutang Terhadap Likuiditas.}

Hasil dari pengujian membuktikan bahwa perputaran piutang tidak memiliki pengaruh yang signifikan terhadap likuiditas. Dengan nilai signifikansi t 0,112>0.05, sehingga Ho gagal ditolak. Penelitian ini berbeda dengan penelitian yang dilakukan oleh Ridwan (2009) yang menyatakan bahwa perputaran piutang memiliki pengaruh yang signifikan terhadap likuiditas. Hasil penelitian ini menunjukkan bahwa perputaran piutang tidak memiliki pengaruh yang signifikan terhadap likuiditas, maka perputaran piutang tidak dapat dijadikan bahan pertimbangan pengaruh dalam likuiditas 
perusahaan industri barang konsumsi yang terdaftar di Bursa Efek Indonesia selama periode penelitian.

Perbedaan ini dikarenakan adanya perbedaan jenis industri perusahaan yang digunakan dengan penelitian sebelumnya. Penelitian yang dilakukan oleh Ridwan (2009) menggunakan objek satu organisasi saja yang terdapat dalam industri farmasi. Secara teori, banyak faktor yang dapat mempengaruhi tingkat likuiditas pada perusahaan. Tidak hanya diukur melalui perputaran piutang saja, aktiva lancar lainnya dan hutang lancar juga memiliki peranan yang menentukan dalam besarnya tingkat likuiditas perusahaan. Faktor-faktor tersebutlah yang menyebabkan terjadinya perbedaan pada hasil penelitian pengaruh perputaran piutang terhadap likuiditas. Selain itu tidak signifikannya penelitian ini diduga disebabkan dari krisis global yang menyebabkan meningkatnya piutang dan penjualan yang tetap sehingga kebutuhan tambahanpun mendesak yang mengakibatkan penjualan menurun.

Hasil penelitian ini sejalan dengan hasil penelitian yang dilakukan oleh Putra (2010) yang menyatakan bahwa perputaran piutang tidak memiliki pengaruh yang signifikan terhadap likuiditas perusahaan.

\section{c. Pengaruh Tingkat Pertumbuhan Penjualan Terhadap Likuiditas.}

Hasil dari pengujian menunjukkan bahwa tingkat pertumbuhan penjualan secara parsial berpengaruh negatif signifikan terhadap likuiditas pada perusahaan industri barang konsumsi yang terdaftar di Bursa Efek Indonesia 2011 - 2013. Hasil ini sesuai dengan nilai signifikansi t untuk variabel pertumbuhan penjualan yaitu sebesar 0,003 yang lebih kecil dari 0.05. Berdasarkan hasil tersebut menunjukkan bahwa peningkatan pertumbuhan penjualan tidak diikuti dengan peningkatan likuiditas, artinya jika tingkat pertumbuhan penjualan meningkat hal ini malah akan menurunkan likuiditas. Hasil ini bertimbal balik dengan hipotesis yang menyatakan bahwa tingkat pertumbuhan penjualan berpengaruh positif signifikan dengan likuiditas.

Hasil penelitian ini sejalan dengan hasil penelitian Falahi (2010) yang menyatakan bahwa pertumbuhan penjualan berpengaruh secara signifikat terhadap likuiditas pada perusahaan retail yang terdaftar di Bursa Efek Indonesia.

Hasil penelitian diatas sejalan dengan teori yang diungkapkan sebelumnya. Sebagaimana teori yang diungkapkan pada penelitian ini bahwa penjualan sangat berpengaruh terhadap tingkat likuiditas perusahaan karena komponen penjualan yang berupa aktiva lancar (kas dan piutang) merupakan komponen dalam menghitung tingkat likuiditas. Seyogianya, semakin banyak penjualan dan atau semakin tinggi perputaran piutang maka semakin tinggi pula nilai aktiva lancar sehingga tingkat likuiditas turut mengalami kenaikan. 


\section{KESIMPULAN, KETERBATASAN, DAN SARAN}

\section{Kesimpulan}

Berdasarkan hasil pengujian dan pembahasan mengenai pengaruh variabel independen yang berupa Perputaran Persediaan, Perputaran Piutang dan Tingkat Pertumbuhan Penjualan terhadap likuiditas pada perusahaan barang konsumsi yang terdaftar di Bursa Efek Indonesia selama periode 20112013, maka dapat ditarik beberapa kesimpulan mengenai penelitian tersebut, antara lain:

a. Perputaran Persediaan tidak memiliki pengaruh yang signifikan terhadap likuiditas perusahaan pada sektor industri barang konsumsi yang terdaftar di Bursa Efek Indonesia.

b. Perputaran piutang tidak memiliki pengaruh yang signifikan terhadap likuiditas perusahaan pada sektor industri barang konsumsi yang terdaftar di Bursa Efek Indonesia.

c. Tingkat Pertumbuhan penjualan berpengaruh negatif signifikan terhadap likuiditas perusahaan pada sektor industri barang konsumsi yang terdaftar di Bursa Efek Indonesia.

d. Perputaran persediaan, perputaran piutang, tingkat pertumbuhan penjualan secara simultan berpengaruh signifikan terhadap likuiditas pada perusahaan industri barang konsumsi yang terdapat di Bursa Efek Indonesia.

e. Berdasarkan uji koefisien determinasi likuiditas dijelaskan oleh perubahan perputaran pesediaan, perputaran piutang, dan tingkat pertumbuhan penjualan sebesar $14,6 \%$ sedangkan sisanya $85,4 \%$ dipengaruhi oleh faktor-faktor lain diluar variabel yang diteliti antara lain Perputaran Modal Kerja, kas, dan dividen

\section{Keterbatasan Penelitian}

Terdapat beberapa keterbatasan dalam penelitian ini yang dapat dijadikan bahan pertimbangan untuk penelitian selanjutnya, yaitu:

a. Periode pengamatan dalam penelitian ini memiliki jangka waktu yang singkat yaitu 3 tahun, dimulai dari tahun 2011, 2012 sampai dengan 2013.

b. Variabel independen (bebas) yang digunakan dalam penelitian ini hanya terbatas pada tiga variabel.

\section{Saran}

Berdasarkan hasil penelitian yang telah dilakukan, maka ada beberapa hal yang dapat disarankan oleh penulis bagi peneliti selanjutnya yaitu : 
a. Peneliti selanjutnya diharapkan menambahkan variabel lain karena dalam penelitian ini variabel independen hanya mampu menjelaskan variabel dependen sebesar 14,6\%, sedangkan sisanya sebesar $85,4 \%$ dipengaruhi oleh faktor-faktor lain di luar variabel yang diteliti.

b. Peneliti selanjutnya diharapkan menggunakan objek penelitian selain perusahaan barang konsumsi, karena masih banyak jenis perusahaan yang terdaftar di Bursa Efek Indonesia.

c. Pengukuran likuiditas dapat diukur menggunakan rasio lain selain rasio lancar, seperti rasio cepat, dan rasio kas.

d. Peneliti selanjutnya disarankan untuk menambah periode pengamatan yaitu lebih dari 3 tahun.

\section{DAFTAR PUSTAKA}

Andina Nabila. 2012. "Pengaruh Tingkat Pertumbuhan Penjualan Perputaran Piutang Terhadap Tingkat Likuiditas Pada Perusahaan Manufaktur Makanan dan Minuman Yang Terdaftar Di Bursa Efek Indonesiaa", Skripsi Sarjana, Fakultas Ekonomi USU : Medan

Debbianita. 2012. "Pengaruh perputaran Piutang dan Perputaran Modal Kerja Terhadap Likuiditas perusahaan (Studi Kasus pada Perusahaan Manufaktur Sektor Industri Barang Konsumsi yang Terdaftar di Bursa Efek Indonesia 2008-2011)", Skripsi, Universitas Kristen Maranatha : Bandung.

Dunia, F. A. 2008. Pengantar Akuntansi Edisi Ketiga. Jakarta: Fakultas Ekonomi Universitas Indonesia.

Falahi, Muhammad Ilyas. 2010. "Pengaruh Siklus Konversi Kas dan Pertumbuhan Penjualan Terhadap Likuiditas Pada Perusahaan Retail yang Terdaftar di Bursa Efek Indonesia". Skripsi, Universitas Pembangunan Nasional "Veteran" : Jakarta.

Ghozali, Iman. 2013. Aplikasi Analisis Multivariate dengan Program IBM SPSS 21, Edisi ketujuh, Semarang : Universitas Diponegoro.

Higgins, Robert C. 2003. Analysis for Financial Management, Seventh Edition, McGraw-Hill, Singapore.

Horngren, Harrison JR., dan Bamber. 2006. Akuntansi Alih bahasa: Barlian muhammad. Edisi keenam jakarta, Indeks

James C. Van Horne dan John M. Wachowicz. 2005. Prinsip-Prinsip Manajemen Keuangan. Edisi kedua belas. Jakarta: Salemba Empat.

Jumingan. 2011. Analisis Laporan Keuangan, Aksara: Jakarta.

Kasmir. 2012. Analisis Laporan Keuangan, Jakarta : PT Rajagrafindo Persada.

Keown, et al. 2008. Manajemen Keuangan. Alih Bahasa: Widodo. Ed. 10, Jakarta: Cemerlang. 
Muharsyah, Rian, Khairani, Siti, Aprilia, Rini. 2012. "Pengaruh Tingkat Pertumbuhan Penjualan dan Perputaran Piutang Terhadap Likuiditas Perusahaan Pada Perusahaan Otomotif dan Komponennya yang Terdaftar di Bursa Efek Indonesia”. Jurnal, STIE MDP : Palembang.

Milawati, 2010. "Pengaruh Perputaran piutang Terhadap Tingkat Likuiditas Pada PT. Sepatu Bata Tbk", Universitas Komputer Indonesia : Bandung. Moeljadi. 2006. Manajemen Keuangan Pendekatan Kuantitatif dan Kualitatif, BPFE: Yogyakarta.

Munawir. 2004. Analisis Laporan Keuangan, Edisi keempat, Yogyakarta : Liberty.

Prihadi Toto. 2010. Analisis Laporan Keuangan, Jakarta : PPM.

Putra, Oktianda Yudi. 2010. "Pengaruh Tingkat Pertumbuhan Penjualan dan Tingkat Perputaran Piutang Terhadap Tingkat Likuiditas Pada Perusahaan Manufaktur Makanan dan Minuman yang Terdaftar di Bursa Efek Indonesia”. Skripsi, Universitas Sumatera Utara : Medan.

Rudianto. 2009. Pengantar Akuntansi.Penerbit Erlangga.

Ridwan, Rizal Bustanul. 2009. "Pengaruh Perputaran Piutang Terhadap Tingkat Likuiditas Pada PT. Kalbe Farma Tbk Periode 2002-2008". Skripsi, Universitas Komputer Indonesia : Bandung.

Stice, Earl K, Stice, James D dan Skousen, K. Fred, 2009. Akutansi Keuangan, Jakarta : Salemba Empat.

Sugiyono. 2009. Metode Penelitian Kuantitatif Kualitatif dan R\&D, Cetakan kedelapan, Bandung : Alfabeta.

Sunyoto Danang. 2013. Dasar-Dasar Manajemen Keuangan Perusahaan, Yogyakarta : CAPS (Center of Academic Publishing Service).

Suseno, Agus. 2009. Pengaruh Perputaran Persediaan Terhadap Likuiditas Pada PT. Unilever Indonesia Tbk. Skripsi S1. Universitas Komputer Indonesia, Bandung.

Vendy Widhiatmojo dan Supriyanto. 2012. Pengaruh Perputaran Piutang, Kas dan Persediaan Barang Terhadap Tingkat Likuidtas Koperasi, Jurnal Pendidikan dan Ekonomi Volume II, Nomor 6.

Wild, John J.; K.R. Subramanyam; dan Robert F. Halsey. 2010. Financial Statement Analysis: Analisis Laporan Keuangan. Yang Diterjemahkan Oleh: Yanivi S. Bachtiar dan S. Nurwahyu Harahap. Edisi Kedelapan. Jakarta: Salemba Empat.

http://www.idx.co.id/ 